\title{
Genetic Parameters of Claw and Foot Disorders Estimated with Logistic Models
}

\author{
S. Koenig, ${ }^{1}$ A. R. Sharifi, ${ }^{1}$ H. Wentrot, ${ }^{1}$ D. Landmann, ${ }^{2}$ M. Eise, ${ }^{3}$ and H. Simianer ${ }^{1}$ \\ ${ }^{1}$ Institute of Animal Breeding and Genetics, University of Göttingen, 37075 Göttingen, Germany \\ ${ }^{2}$ Experimental Station for Animal Husbandry of LWK Hannover, 21379 Echem, Germany \\ ${ }^{3}$ German Agricultural Society (DLG), 60489 Frankfurt, Germany
}

\section{ABSTRACT}

The primary aim of this study was to estimate heritabilities for different types of claw and foot disorders and the genetic relationship of disorders with milk yield and selected conformation traits by applying logistic models in Holstein dairy cattle. The study included data from 5634 Holstein cows kept on large-scale dairy farms in Eastern Germany. Dichotomous response variables were the presence or absence of the disorder in 2003. Cows that were present in herds for $<6$ wk in 2003 were excluded from the analysis. Incidences, disregarding repeated measurements, for digital dermatitis (DD), sole ulceration (SU), wall disorder (WD), and interdigital hyperplasia $(\mathrm{IH})$ in rear legs were $13.2,16.1,9.6$, and $6.3 \%$, respectively. The herd effect was highly significant for all disorders. Incidences increased with increasing parities for SU and WD, but were highest among heifers for DD. High milk yield at the first 2 test $d$ after calving was associated with a greater risk for claw and foot disorders in the same lactation. Estimates of heritability were 0.073 for DD, 0.086 for SU, 0.104 for WD, and 0.115 for IH. Genetically, health problems appear to occur in clusters (i.e., a cow showing one disease has an increased genetic risk of showing another claw disease). This phenomenon was also observed between claw and foot disorders and the somatic cell score. Genetic correlations between milk yield in early lactation and disorders were 0.240 for DD, 0.057 for SU, 0.270 for WD, and 0.336 for $\mathrm{IH}$, indicating a physiological antagonism. Correlations between breeding values for claw and foot disorders of bulls and official breeding values for functional type traits were mostly favorable. Routine recording of claw data will offer a new chance to improve claw health within the population as was elaborated by different scenarios applying selection index procedures.

(Key words: Generalized Linear Mixed model, claw and foot disorder, genetic parameters)

Received January 25, 2005.

Accepted May 7, 2005.

Corresponding author: Sven Koenig; e-mail: skoenig2@gwdg.de.
Abbreviation key: DD = digital dermatitis, $\mathbf{I H}=$ interdigital hyperplasia, $\mathbf{S U}=$ sole ulceration, $\mathbf{W D}=$ wall disorder.

\section{INTRODUCTION}

As the level of milk production in dairy cattle increases, correlated increases in health problems need to be studied in more detail. Health problems result in higher culling rates, increased veterinary costs, and economic losses caused by lower production and discarded milk. In recent years, research on health traits has focused on fertility and mastitis. In the Nordic countries, for example, clinical mastitis has been included in dairy cattle breeding objectives since the late 1970s. Genetic evaluation is based on defining the trait as a binary response in a linear model (Heringstad et al., 2000). In Germany, inclusion of health traits in selection programs has been limited because of a lack of reliable data on disease events. In addition, the discrete nature of most disease observations makes their statistical analysis and interpretation more difficult (Mäntisaary et al., 1991).

In the last $10 \mathrm{yr}$, involuntary culling because of feet and leg disorders is of increasing relevance. Results of a survey by the National Animal Health Monitoring System (APHIS, 1996) in the United States reported that $15 \%$ of all cullings were directly due to lameness or leg injury. In Germany, cullings because of feet and leg disorders among all cullings were reported to be $3.2 \%$ in 1980 and $9.1 \%$ in 2000 , as shown in annual statistics published by the German Cattle Breeders Federation (ADR, 1980-2000). Enting et al. (1997) concluded that clinical lameness is one of the most costly diseases in dairy cattle. The economical loss attributable to feet and leg disorders in a 100-cow herd in Great Britain was 8000 Euro/yr on average (Kossaibati and Esslemont, 2000). Much of the variability in feet and leg health is associated with environmental effects, but a few studies have revealed a genetic impact on such traits. An overview of published heritability estimates for different types of claw and foot disorders and related traits in different dairy breeds since 1990 is given in 
Table 1. Heritability estimates for different types of claw and foot disorders and related traits in dairy cattle.

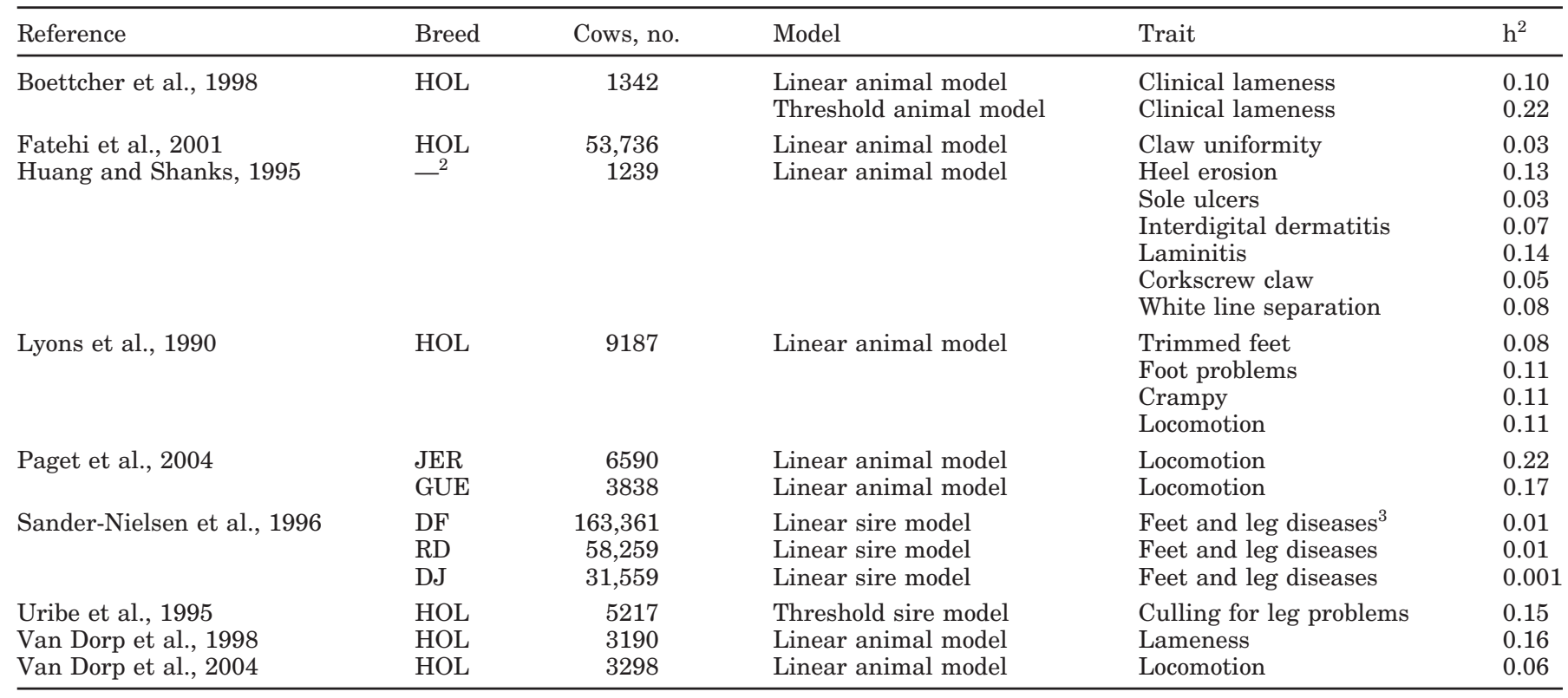

${ }^{1} \mathrm{HOL}=$ Holstein-Friesian, JER = Jersey, GUE = Guernsey, DF = Danish Friesian, RD = Red Danish, and DJ = Danish Jersey.

${ }^{2} 1239$ cows of 5 breeds: Ayrshire, Brown Swiss, Guernsey, Holstein, and Jersey.

${ }^{3}$ Feet and leg diseases include heel erosion, interdigital dermatitis, interdigital necrobacillosis, interdigital skin hyperplasia, laminitis, arthritis, sole ulcer, pressure injuries, and tenosynovitis of hooves.

Table 1. Several papers have focused their investigations on locomotion or overall feet and leg problems. Detailed research on different claw and foot disorders, including relatively large data sets comparable with our study, was only done by Huang and Shanks (1995). For selection to be effective, reliable estimates of genetic parameters of claw and foot disorders are needed to determine the amount of genetic variation available. Correlations with other variables of economic importance are also required to allow the development of a combined breeding value for production and functional traits.

The intent of this work was to estimate heritabilities of some clinical claw and foot diseases of Holstein dairy cows kept in large-scale dairy farms in Eastern Germany and to measure genetic and environmental correlations between diseases and production traits. Milk secretion in dairy cows has a high metabolic priority and is clearly maintained at the cost of other reproductive and metabolic processes (Fleischer et al., 2001). To assess the impact of physiological stress, much attention was given to the impact of milk yield at the beginning of lactation on claw and foot disorders in the following stage of lactation. Furthermore, EBV for claw and foot disorders of widely used sires were correlated with the official breeding values of these sires for some type traits. Results revealed to what extent claw and foot disorders are sufficiently covered by the type recording schemes implemented today in Germany.

\section{MATERIALS AND METHODS}

\section{Materials}

The data set comprised test-day production records and claw and foot disorders recorded in 2003 from 5634 Holstein cows on 9 large-scale dairy farms from one region in Eastern Germany collected by 9 different hoof trimmers. The guideline for classification of individual claw and foot disorders was developed by the German Agricultural Society, and all trimmers were trained for uniform identification of traits. Claw and foot diseases were divided into 4 different categories digital dermatitis (DD), sole ulcer (SU), wall disorder (WD), and interdigital hyperplasia (IH) (Figure 1) and were analyzed separately. Interdigital hyperplasia and to a large degree, DD, are foot disorders that do not directly affect the medial or distal claw on each foot, whereas SU and WD belong to classical claw disorders. Wall disorder mainly describes the different types of white-line disease and further lesions along the wall of the claw. A few specific cases of heel erosion were considered together with digital dermatitis, because both disorders are caused by bacteria. Disorders were scored on an all-or-none basis. If a cow had the health problem in one or both rear legs, she was given a score of 1 ; otherwise, she was given a score of 0 . Repeated measurements of same claw and foot diseases were not taken into account; hence, no effects of lactation stage were considered in the model. Cows that were present in 


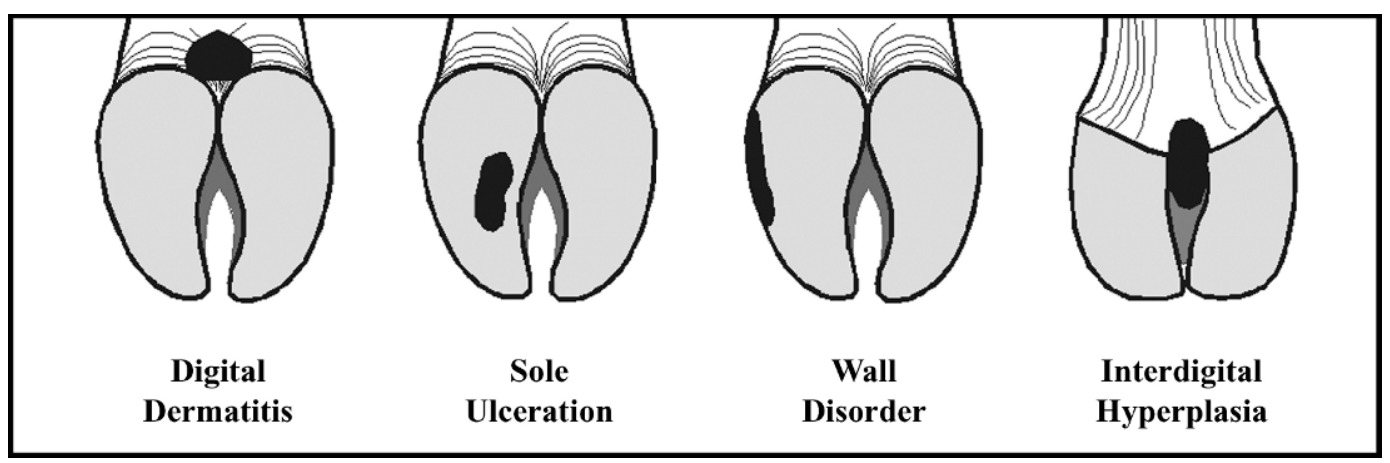

Figure 1. Localization of investigated claw and foot disorders as defined for this study.

herds for $<6$ wk in 2003 were excluded from the analysis. Therefore, each cow was given at least a 6 -wk opportunity in 2003 to exhibit claw or feet disorders. Production traits were averaged from the first 2 test $d$ of cows calving in 2003. This was done to define the production level in early lactation. The interval between 2 test $d$ in the official German milk recording system is generally 4 wk. Analogous to milk yield, SCC was averaged from first 2 test $\mathrm{d}$ after calving. The monthly test-day SCC was log-transformed into monthly test-day SCS to achieve normality and homogeneity of variances as SCS $=\log _{2}(\mathrm{SCC} / 100,000)+3$ (Ali and Shook, 1980).

For 41 sires with at least 40 daughters in the claw database, correlations between EBV of linear type traits (official national German EBV from February 2004) and breeding values of claw or foot disorders were calculated. Because the simple correlation between estimated breeding values for disorders and EBV for type traits does not fully reflect the genetic relationship between the traits, adjustments were made to approximate the genetic correlations.

\section{Statistical Models}

Because disorders were treated as binary traits, the residuals cannot be normally distributed. The best function to describe the relationship between the dependent and independent variables is not linear, but rather Sshaped. This is the primary reason why a linear logistic model with mixed effects was used. As described by Rodriguez-Zas et al. (1997), the probability of observing the event of interest (e.g., claw and foot disorder) was

$$
\pi_{\mathrm{i}}=\operatorname{Prob}\left(\mathrm{Y}_{\mathrm{i}}=1 \mid \theta\right)
$$

where $\theta$ is a parameter vector including fixed and random effects. The logit of the observation $Y_{i}$ was

$$
\log \left[\frac{\pi_{i}}{1-\pi_{i}}\right]=\eta_{\mathrm{i}}
$$

Because $\pi$ is the probability that $\mathrm{Y}=1$, it follows that $1-\pi$ is the probability of $\mathrm{Y}=0$; so, $\frac{\pi}{1-\pi}$ is the ratio of the 2 probabilities, which, when stated in the form of odds, gives the odds of having $\mathrm{Y}=1$. Any factor that increased $\eta_{\mathrm{i}}$ led to a concomitant increase in $\pi_{\mathrm{i}}$. A linear model can be imposed on the vector of logits such that

$$
\eta=\mathrm{X} \beta+\mathrm{Zu}
$$

where

$$
\begin{aligned}
& \eta= \mathrm{N} \times 1 \text { vector of logits }(\mathrm{N}=\text { number of observa- } \\
&\text { tions }) \\
& \mathrm{X}= \mathrm{N} \times \mathrm{p} \text { incidence matrix }(\mathrm{p}=\text { number of levels of } \\
&\text { fixed effects }) \\
& \beta= \mathrm{p} \times 1 \text { vector of fixed effects, } \\
& \mathrm{Z}=\mathrm{N} \times \mathrm{C} \text { incidence matrix }(\mathrm{C}=\text { number of animals }), \\
& \quad \text { and } \\
& \mathrm{u}=\mathrm{C} \times 1 \text { vector of random effects. }
\end{aligned}
$$

Unlike linear models, there is no error term in the equation. The residual variability contained in the residual of the linear mixed model equation is incorporated in the variance function of the generalized mixed model. The residual variance [i.e., the variance of the observations given $\eta_{\mathrm{i}}\left(\right.$ or $\left.\pi_{\mathrm{i}}\right)$ ] stems from binomial sampling; hence,

$$
\operatorname{Var}\left(\mathrm{Y}_{\mathrm{i}} \mid \pi_{\mathrm{i}}\right)=\pi_{\mathrm{I}}\left(1-\pi_{\mathrm{i}}\right) .
$$

First analysis of variance of the measurements was carried out using logistic models implemented in the SAS glimmix macro (Wolfinger and O'Connell, 1993), which included the fixed effects of the herd and lactation 
number as well as a regression on milk yield up to the third polynomial degree in order to fit regression curves. Interaction between lactation number and milk yield in linear and exponential terms was also considered in model statements. Non-significant regression coefficients of different polynomial structure were removed from the model by using Sum of Square Type I tests (Wald-type tests) and $F$-statistics at $P<0.05$ rather than likelihood ratio tests. Sum of Square Type I tests provide a sequential analysis approach that is appropriate for polynomial-formulated models. The $F$-ratios used in the analysis of variance are identical to the Wald/rank(K) $F$-statistics as defined by Littell et al. (1999). Wald-type tests were also used to identify significant fixed effects on claw and foot disorders (type III tests of fixed effects).

The final generalized linear model used to determine the impact of environmental effects and covariates on the incidence of disorders for WD and IH was

$$
\begin{gathered}
\operatorname{logit}\left(\pi_{\mathrm{rst}}\right)=\log \left[\frac{\pi_{r s t}}{1-\pi_{r s t}}\right]= \\
\eta_{\mathrm{rst}}=\varphi=\gamma_{\mathrm{r}}+\lambda_{\mathrm{s}}+\mathrm{b}_{1} \mathrm{Y}_{\mathrm{rst}}+\mathrm{b}_{2} \mathrm{Y}_{\mathrm{rst}}^{2}+\mathrm{b}_{3} \mathrm{Y}_{\mathrm{rst}}^{3}
\end{gathered}
$$

where

$$
\begin{aligned}
\pi_{\mathrm{rst}}= & \text { probability of occurrence for claw and foot } \\
& \text { disorder of cow } \mathrm{t} \text { in parity } \mathrm{r} \text { and herd } \mathrm{s}, \\
\varphi= & \text { overall mean effect, } \\
\gamma_{\mathrm{r}}= & \text { fixed effect of parity } \\
\gamma_{\mathrm{s}}= & \text { fixed herd effect, } \\
\mathrm{Y}_{\mathrm{rst}}= & \text { average milk yield of test } \mathrm{d} 1 \text { and test } \mathrm{d} 2 \\
& \text { of cow } \mathrm{t} \text { in parity } \mathrm{r} \text { and herd } \mathrm{s}, \text { and } \\
\mathrm{b}_{1}, \mathrm{~b}_{2}, \mathrm{~b}_{3}= & \text { linear, quadratic, and cubic regressions of } \\
& \text { claw and foot disorder on milk yield. }
\end{aligned}
$$

For SU, the linear regression gave the best fit; whereas, for DD, the effect of milk yield was not significant at all.

The inverse link function is defined as $\mathrm{h}(\eta)=\mu$. The inverse link was used to obtain predicted values of $\mu$ from the estimated $\beta$ vector in $\eta_{\mathrm{i}}=\mathrm{X} \beta$. For the normal distribution, $\mathrm{h}(\mathrm{X} \beta)=\mathrm{X} \beta$. For the binomial, $\eta=\log [(\pi /$ $1-\pi)$; hence, $\pi=\mathrm{h}(\mathrm{X} \beta)=\exp (\mathrm{X} \beta) /[1+\exp (\mathrm{X} \beta)]$.

Estimation of variance components was done using univariate animal models for REML and applying the package ASREML (Gilmour et al., 1998), including logistic link functions. The model for genetic analysis is extended to:

$$
\begin{gathered}
\operatorname{logit}\left(\pi_{\mathrm{rst}}\right)=\log \left[\frac{\pi_{r s t}}{1-\pi_{r s t}}\right]= \\
\eta_{\mathrm{rst}}=\varphi+\gamma_{\mathrm{r}}+\lambda_{\mathrm{s}}+\tau_{\mathrm{t}}
\end{gathered}
$$

where

$$
\begin{aligned}
\pi_{\mathrm{rst}}= & \text { probability of occurrence for claw and foot disor- } \\
& \text { der of cow } \mathrm{t} \text { in parity } \mathrm{r} \text { and herd } \mathrm{s}, \\
\varphi= & \text { overall mean effect } \\
\gamma_{\mathrm{r}}= & \text { fixed effect of parity } \\
\lambda_{\mathrm{s}}= & \text { fixed herd effect }, \text { and } \\
\tau_{\mathrm{t}} & =\text { random animal effect }
\end{aligned}
$$

Heritabilities were calculated using the variance of the logit link function. This implies a correction of the residual variance by factor $\pi^{2} / 3$ (Southey et al., 2003). Estimates of random effects of animals (EBV) were also calculated in a univariate model. The data set of EBV of sires was subsequently edited such that each sire in the data set $h a d \geq 40$ daughters. This editing for progeny group size of sires was to ensure that EBV of sires from this part of the analysis were sufficiently reliable. Bivariate analyses were carried out to estimate correlations between disorders and production traits, using a combined logistic and linear model. Fixed effects for the logistic and linear model were the same as for the univariate analysis. Genetic correlations between binomially distributed traits (claw and foot disorders) were also estimated via ASREML using the logit link function. Genetic correlations between normally distributed traits (milk yield, SCS) were estimated using the identity link function.

Approximate transformations of correlations between EBV for disorders and EBV for type traits into genetic correlations between traits was done as suggested by Calo et al. (1973) and Blanchard et al. (1983):

$$
\tilde{r}_{\mathrm{g}_{1,2}}=\frac{\sqrt{\left(\sum_{i} R_{i_{1}}\right) *\left(\sum_{i} R_{i_{2}}\right)}}{\sum_{i}\left(R_{i_{1}} * R_{i_{2}}\right)} * r\left(E B V_{1}, E B V_{2}\right),
$$

where $R_{i_{\mathrm{j}}}$ is the reliability of the EBV of bull $\mathrm{i}$ in trait j. Reliabilities for individual sires and different claw and foot disorders were calculated applying selection index procedures. Only progeny records of bulls were considered as information sources in approximate index calculations. For the interpretation of correlations between breeding values, it is essential to know that higher values for official EBV of type traits are generally favorable. For claw and foot disorders, low EBV indicate genetically favorable bulls with fewer diseased daughters.

Utilized heritabilities for claw and foot disorders in index procedures were from results in the present study. Reliabilities for individual sires and different traits were in a range between 0.43 and 0.92 , indicating 
Table 2. Incidences of different types of claw and foot disorders on large-scale dairy farms.

\begin{tabular}{lllll}
\hline & $\begin{array}{l}\text { Digital } \\
\text { dermatitis }\end{array}$ & $\begin{array}{l}\text { Sole } \\
\text { ulcer }\end{array}$ & $\begin{array}{l}\text { Wall } \\
\text { disorder }\end{array}$ & $\begin{array}{l}\text { Interdigital } \\
\text { hyperplasia }\end{array}$ \\
\hline Best herd & 0.018 & 0.019 & 0.005 & 0.007 \\
Average & 0.132 & 0.161 & 0.096 & 0.063 \\
Worst herd & 0.418 & 0.324 & 0.185 & 0.167 \\
\hline
\end{tabular}

the variation in the number of daughters per sire: 41 to 637 .

\section{RESULTS AND DISCUSSION}

\section{Mean Incidence}

Table 2 gives an overview of mean incidences of claw and foot disorders in the complete data and in herds with highest and lowest incidences for each trait. Mean incidences of observed claw and foot disorders of Holstein cows on large-scale dairy farms were in a wide range as reported in the literature, mainly in veterinarian studies. Prevalences for lameness associated with SU or WD of 8 to $15 \%$ in US studies (Wells et al., 1993; Warnick et al., 2001) and an average prevalence of $20.6 \%$ in Britain (Clarkson et al., 1996) were reported. In our study, we found an incidence for SU of $16.1 \%$, and $22.1 \%$ of the cows were diagnosed for SU and/or WD. For DD, observed incidences $(13.2 \%)$ were lower than found by Somers et al. (2003) in Holstein cows in The Netherlands. All investigated herds in The Netherlands were infected by DD, resulting in an average cow level prevalence of $30 \%$. This indicates that the level of DD infection has increased considerably over the last $10 \mathrm{yr}$ in The Netherlands. The frequency of cows with at least one treatment because of feet and leg diseases was 6\% in Danish Holsteins in a period from 0 to 4 mo after calving and is, therefore, at a low level (Hansen et al., 2001). Smits et al. (1992) surveyed the prevalence of IH from 34 purebred and crossbred Holstein-Friesian and Dutch-Friesian herds. Incidences, about $8.8 \%$, were slightly higher than found in our study. Huang and Shanks (2002) investigated claw and foot disorders on 4722 records of 1239 cows in 5 dairy breeds. The incidence of defect on any claw over a lifetime was $4.2 \%$ for $\mathrm{IH}$.

As shown in Table 2, differences in claw and foot disorders between herds were remarkable. We have tried to explain such differences by information collected in herd management programs. This attempt was not successful. For example, the best and the worst herd for SU used identical management strategies: feeding total mixed rations, $2 \mathrm{~h}$ pasture/d for lactating cows, and the same husbandry system and floor surfaces. Nevertheless, manifold other risk factors and
Table 3. Least squares means for incidences of different claw and foot disorders stratified by parities.

\begin{tabular}{lllll}
\hline Parity & $\begin{array}{l}\text { Digital } \\
\text { dermatitis }\end{array}$ & $\begin{array}{l}\text { Sole } \\
\text { ulcer }\end{array}$ & $\begin{array}{l}\text { Wall } \\
\text { disorder }\end{array}$ & $\begin{array}{l}\text { Interdigital } \\
\text { hyperplasia }\end{array}$ \\
\hline 1 & 0.139 & $0.139^{\mathrm{a}}$ & $0.059^{\mathrm{a}}$ & 0.058 \\
2 & 0.133 & $0.147^{\mathrm{a}}$ & $0.094^{\mathrm{b}}$ & 0.066 \\
$>2$ & 0.125 & $0.185^{\mathrm{b}}$ & $0.167^{\mathrm{c}}$ & 0.070 \\
\hline
\end{tabular}

a,b,c Different superscripts within columns indicate significant differences $(P<0.05)$.

their interactions causing feet and leg disorders within strata can be assumed. Total mixed rations for example are varying with their ratios of roughage to concentrate, their excess protein supply, or their supply of minerals, histamine, and amino acids (cystine, methionine). Analyzing these factors clearly was beyond the scope of this study. Herd's hoof care practices, such as the frequency of trimming, were identical on all farms.

\section{Fixed Effects and Covariates}

In the first analysis, fixed logistic models were used to determine the environmental effects on claw and foot diseases. Herd effect significantly $(P<0.001)$ affected all disorders, whereas parity was only significant for WD and SU $(P<0.05)$. As expected, incidences of these diseases increased with increasing parities (Table 3). Enevoldsen and Gröhn (1990) found similar results when analyzing sole ulcer occurrence in 23 Danish herds composed of 3328 Danish Black and White cows, which are comparable with Holstein-Friesian. They reported SU occurrence in one foot in $20.0 \%$ of cows in lactation 1 and in $23.5 \%$ of cows in lactations 2 to 9 . Incidences of IH found by Smits et al. (1992) increased by parities and were $3.4,9.4$, and $11.6 \%$ in parities 1 , 2 , and $\geq 3$, respectively. We found that heifers liability to DD was slightly above the incidence of adult cows (i.e., $13.9 \%$ in parity 1 and $12.5 \%$ in parity $\geq 3$ ). Also, an effect of selection is anticipated. Healthy cows have fewer disease problems and have a greater opportunity to reach the subsequent parity. Especially on largescale farms in Eastern Germany, selection pressure is high, and replacement rates are increasing steadily (Bergfeld, 2004).

High milk yield in early lactation stratified for different parities was associated with higher incidences in SU, WD, and IH as illustrated in Figures 2, 3, and 4. The interaction between milk yield and parity was not significant on SU, WD, IH, and DD, respectively. Collard et al. (1999) have shown that high milk yield within the first one-third of lactation increases a cow's risk to be affected with health problems. Those resarchers concluded that metabolic stress occurs when the cow's 


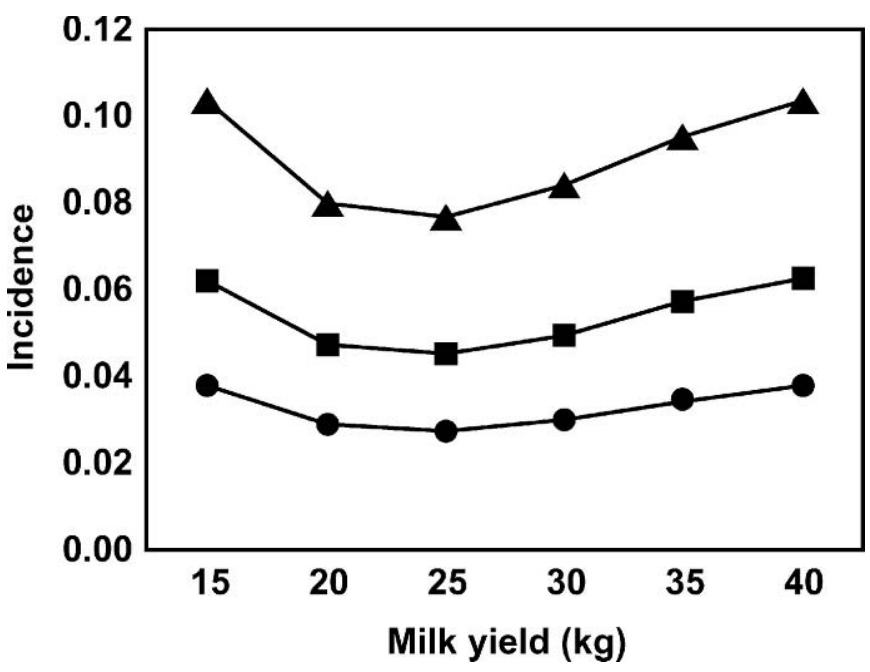

Figure 2. Incidences (least squares means) of wall disorders in parity $1(\bullet), 2(\boldsymbol{\square})$, and $\geq 3(\boldsymbol{\Delta})$ dependent on average milk yield $(\mathrm{kg})$ of test $\mathrm{d} 1$ and 2 after calving.

energy intake does not match its requirement, and the cow is unable to compensate and mobilizes its body reserves too quickly. In their study, increased digestive and locomotive problems were associated with longer and more extreme periods of negative energy balance. In early lactation, cows are fed high-energy diets with relatively low ratios of roughage to concentrate. Such a ration increases the risk of rumen acidosis and related disorders, which are expected to predispose the cow to laminitis. High BW in combination with high milk yield have been postulated by Enevoldsen an Gröhn (1990) as dominant risk factors for sole ulcers. In their study, fat-corrected milk at the first test day was used because

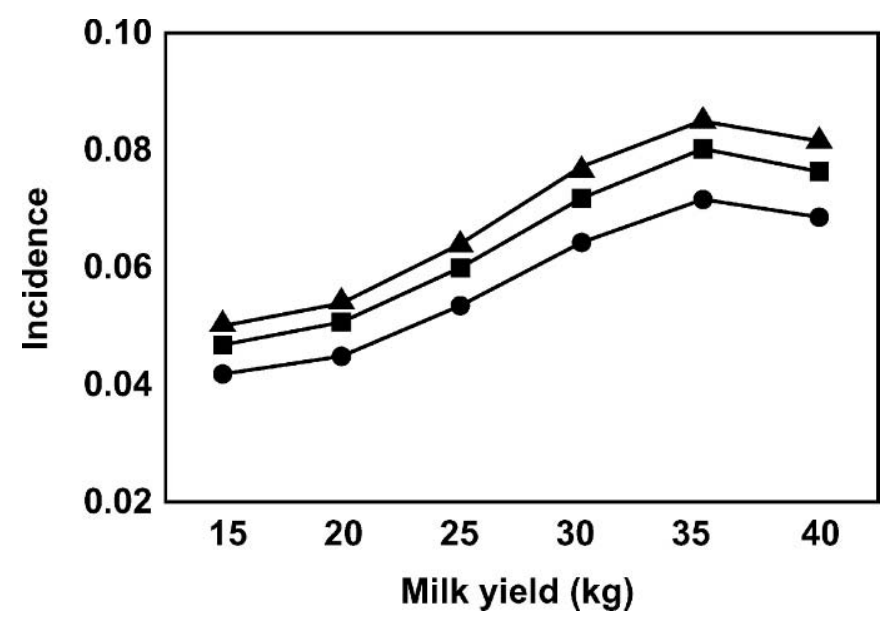

Figure 3. Incidences (least squares means) of interdigital hyperplasia in parity $1(\bullet), 2(\mathbb{\square})$, and $\geq 3(\mathbf{\Delta})$ dependent on average milk yield (kg) of test d 1 and 2 after calving.

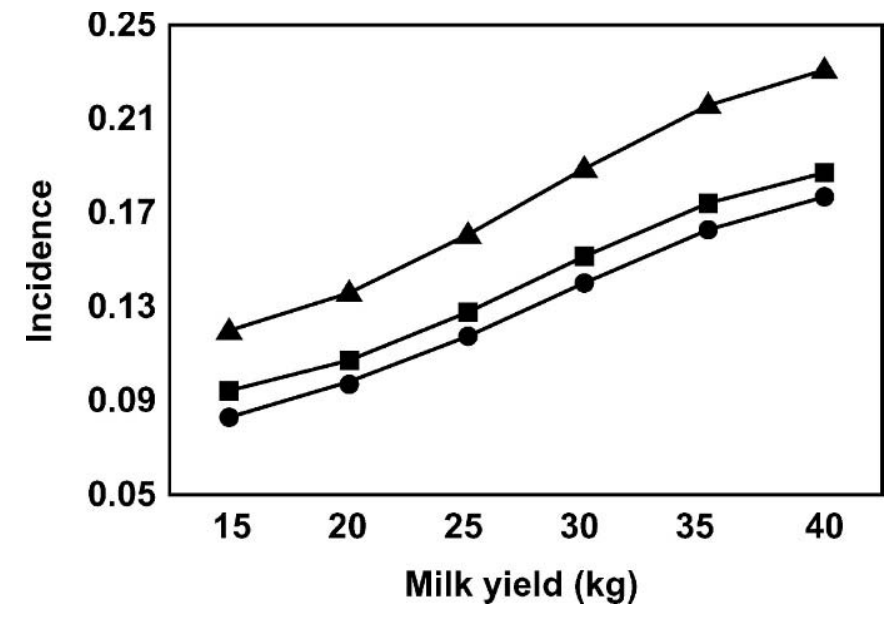

Figure 4. Incidences (least squares means) of sole ulceration in parity $1(\bullet), 2(\boldsymbol{\square})$, and $\geq 3(\boldsymbol{\Delta})$ dependent on average milk yield $(\mathrm{kg})$ of test $d 1$ and 2 after calving.

it was expected to be high for those cows that were fed a high amount of concentrate relative to roughage immediately after calving. In the study of Fleischer et al. (2001), the 305-d yield from the previous and current lactations was used as the standard for milk yield. A higher estimated probability of appearance of claw diseases with increasing lactation yields in the current lactation was observed. Conversely, severe lameness reduces a cow's ability for daily milk production. Warnick et al. (2001) investigated the effect of lameness on milk production in 2 New York dairy farms. In both herds, milk production decreased significantly for cows diagnosed as lame. The decrease was largest for cows in second or later lactations and when the degree of lameness was judged by farm employees to be more severe. In our data, $85 \%$ of diseased cows were first observed $\geq 60 \mathrm{~d}$ after calving. Therefore, the amount of milk yield from test $\mathrm{d} 1$ and test $\mathrm{d} 2$ after calving was less affected by actual claw and foot disorders.

\section{Heritability Estimates}

Table 4 displays results of genetic analysis with respect to heritabilities and genetic correlations. Heritabilities for claw and foot disorders were in a range from 0.073 (DD) to $0.115(\mathrm{IH})$. Maximum likelihood procedures, which can be applied to estimate genetic parameters in logistic models, were used in several investigations to analyze categorical mastitis data in dairy cattle (e.g. Rodriguez-Zas et al., 1997; de Haas et al., 2001). In general, heritabilities were slightly above estimates from linear models. As shown in Table 1, Huang and Shanks (1995) estimated heritabilities for different claw and foot disorders in linear and threshold models. 
Table 4. Heritabilities (diagonal) and genetic correlations (above diagonal) among disease and production traits. Standard errors of estimates are presented in brackets.

\begin{tabular}{|c|c|c|c|c|c|c|}
\hline & $\begin{array}{l}\text { Digital } \\
\text { dermatitis }\end{array}$ & $\begin{array}{l}\text { Sole } \\
\text { ulcer }\end{array}$ & $\begin{array}{l}\text { Wall } \\
\text { disorder }\end{array}$ & $\begin{array}{l}\text { Interdigital } \\
\text { hyperplasia }\end{array}$ & $\begin{array}{l}\text { Milk } \\
\text { yield }\end{array}$ & SCS \\
\hline Digital dermatitis & $\begin{array}{c}0.073 \\
(+0.009)\end{array}$ & $\begin{array}{c}0.561 \\
(+0.073)\end{array}$ & $\begin{array}{c}0.337 \\
(+0.139)\end{array}$ & $\begin{array}{c}0.391 \\
(+0.099)\end{array}$ & $\begin{array}{c}0.240 \\
( \pm 0.145)\end{array}$ & $\begin{array}{c}0.151 \\
( \pm 0.176)\end{array}$ \\
\hline Sole ulcer & & $\begin{array}{c}0.086 \\
( \pm 0.006)\end{array}$ & $\begin{array}{c}0.443 \\
( \pm 0.115)\end{array}$ & $\begin{array}{c}0.498 \\
( \pm 0.112)\end{array}$ & $\begin{array}{c}0.057 \\
( \pm 0.122)\end{array}$ & $\begin{array}{r}0.276 \\
( \pm 0.159)\end{array}$ \\
\hline Wall disorder & & & $\begin{array}{c}0.104 \\
( \pm 0.0014)\end{array}$ & $\begin{array}{c}0.668 \\
( \pm 0.111)\end{array}$ & $\begin{array}{c}0.270 \\
( \pm 0.127)\end{array}$ & $\begin{array}{r}0.187 \\
( \pm 0.173)\end{array}$ \\
\hline Interdigital hyperplasia & & & & $\begin{array}{c}0.115 \\
( \pm 0.021)\end{array}$ & $\begin{array}{c}0.336 \\
( \pm 0.140)\end{array}$ & $\begin{array}{r}0.149 \\
( \pm 0.173)\end{array}$ \\
\hline Milk yield & & & & & $\begin{array}{c}0.277 \\
( \pm 0.031)\end{array}$ & $\begin{array}{c}0.198 \\
( \pm 0.110)\end{array}$ \\
\hline SCS & & & & & & $\begin{array}{r}0.093 \\
( \pm 0.019)\end{array}$ \\
\hline
\end{tabular}

Results of both models were similar. Heritabilities for $\mathrm{SU}$, interdigital dermatitis, and white-line separation estimated in threshold models were $0.024,0.013$, and 0.150 , respectively. White-line separation is an avulsion or separation of the wall of the hoof from the sole and is comparable with wall disorder in our study. In contrast, heritabilities for the individual diseases interdigital dermatitis (0.01), interdigital necrobacillosis (0.00), laminitis (0.01) and SU (0.01) in Danish Holstein were low (Sander-Nielsen et al., 1996). Uribe et al. (1995) defined culling as a result of leg problems as a binomial trait, assuming an underlying threshold model that included fixed and random effects. Sire and residual components of variance were estimated by restricted maximum likelihood, resulting in an estimated heritability of 0.14 . To evaluate clinical lameness in 24 herds in Minnesota, Wisconsin, and Virginia (Boettcher et al., 1998), cows were observed walking and were assigned a score between 0 and 4 , where $4=$ inability to walk. Estimates of heritability were 0.10 and 0.22 from the linear and threshold models, respectively. Paget et al. (2004) classified the linear type traits locomotion and feet and legs on a scale of 1 (poor) to 9 (very good). Heritabilities found in this study were 0.17 for locomotion in Guernsey and 0.22 in Jersey breeds. Heritability estimation for clinical lameness conducted by Van Dorp et al. (1998) in a total of 4368 first lactation records of Holstein cows from 30 herds was 0.16 and thus similar to results found by Distl et al. (1990). In the study of Lyons et al. (1991), heritabilities for individual locomotion traits using producer data supplied by dairy farmers from Wisconsin, Minnesota, and Iowa were $0.14,0.09,0.20$, and 0.09 for trimmed feet, leg problems, foot problems, and crampy, respectively. The heritability estimate of the health category locomotive was 0.16 . Fatehi et al. (2001) estimated genetic parameters for claw traits in Canadian Holstein stratified by housing systems. Heritabilities for claw uniformity were 0.03 in a tie stall and 0.04 in a free-stall barn. Claw uniformity described the relative size of the outer and inner claws of the rear feet. High scores were associated with a uniform size of both claws and fewer disorders. Reported heritability estimates for IH were 0.31 in Simmental dual-purpose cows (Baumgartner and Distl, 1988). In contrast, Greenough (1991) found no evidence for a genetic background of this disease in Holsteins.

\section{Genetic Correlations Between Disorders and Production Traits}

In our study, most genetic correlations among disorders were large and positive (Table 4). Genetically, health problems appear to occur in clusters. The genetic correlations suggest that cows genetically susceptible to some type of health problems are likely to be susceptible to other health problems as well. In the analysis of Lyons et al. (1990), genetic correlations among health traits were positive except for reproduction with mammary and respiratory traits. In their study, the genetic correlation between locomotion and mastitis was 0.09 . We found genetic correlations between SCS and individual claw and foot diseases to range from 0.15 to 0.24 (Table 4).

Selection in dairy cattle has generally focused on increased milk yield, which can have an unfavorable effect on the occurrence of disease. Estimates of phenotypic and genetic correlations between 305-d milk yield and lameness of first lactation cows were 0.04 and 0.24 in a study conducted by Van Dorp et al. (1998), indicating an antagonism. Our estimates for genetic correlations between milk yield of the first 2 test $d$ after calving and the susceptibility to claw and foot disorders ranged between 0.056 for SU and 0.336 for IH. However, standard errors were substantial. The positive genetic correlations indicate that selection or breeding on increased milk yield in the first stage of lactation increases the 
Table 5. Correlations of breeding values for conformation traits with percentage of healthy daughters and with estimated breeding values of claw and foot disorders $\left(\mathrm{r}_{\mathrm{EBV}}\right)$ and approximate genetic correlations of conformation traits with claw and foot disorders $\left(\tilde{r}_{g}\right)$.

\begin{tabular}{|c|c|c|c|c|c|c|c|c|c|c|c|c|}
\hline $\begin{array}{l}\text { Linear-scored } \\
\text { type trait }\end{array}$ & \multicolumn{3}{|c|}{ Digital dermatitis } & \multicolumn{3}{|c|}{ Sole ulcer } & \multicolumn{3}{|c|}{ Wall disorder } & \multicolumn{3}{|c|}{ Interdigital hyperplasia } \\
\hline Feet and leg score & 0.39 & -0.42 & -0.55 & 0.41 & -0.34 & -0.45 & 0.59 & -0.61 & -0.81 & 0.58 & -0.54 & -0.72 \\
\hline Rear leg side view & -0.34 & 0.38 & 0.50 & -0.46 & 0.37 & 0.48 & -0.50 & 0.53 & 0.67 & -0.49 & 0.36 & 0.44 \\
\hline Foot angle & 0.44 & -0.46 & -0.61 & 0.26 & -0.22 & -0.29 & 0.29 & -0.22 & -0.28 & 0.37 & -0.18 & -0.22 \\
\hline Hocks & -0.03 & 0.02 & 0.03 & 0.23 & -0.17 & -0.22 & 0.44 & -0.45 & -0.57 & 0.21 & -0.51 & -0.63 \\
\hline Dairy character & -0.03 & -0.05 & -0.07 & 0.07 & 0.08 & 0.10 & 0.25 & -0.05 & -0.06 & 0.09 & -0.02 & -0.03 \\
\hline Body depth & 0.05 & -0.06 & -0.08 & -0.08 & 0.18 & 0.23 & 0.06 & 0.03 & 0.04 & -0.06 & 0.27 & 0.33 \\
\hline Strength & 0.07 & -0.05 & -0.07 & -0.24 & 0.25 & 0.32 & -0.17 & 0.20 & 0.25 & -0.11 & 0.27 & 0.33 \\
\hline
\end{tabular}

susceptibility to claw and foot disorders in the following lactation stage. Lyons et al. (1991) reported that the genetic correlations between 305-d milk yield and the susceptibility to all categories of health traits, except reproductive disorders, were positive. In detail, genetic correlations with milk yield were 0.48 for trimmed feet, 0.32 for leg problems, 0.31 for foot problems, and 0.37 for crampy. Uribe et al. (1995) found that genetic correlations between culling for leg problems and production of milk, fat, and protein were positive and moderate, indicating that long-term selection for these traits might increase culling for impaired legs. Environmental correlations were negative. In our study, correlations between residuals were near zero. Sander-Nielsen et al. (1996) reported a high genetic correlation between digestive diseases and claw diseases in a range from 0.85 to 0.95 . This might be due to the fact that the most common diseases in feet are caused by physiological problems.

\section{Correlations with Type Traits}

Correlations of estimated breeding values for claw and foot disorders with official breeding values for type traits of bulls are presented in Table 5. However, correlations among breeding values are not identical with genetic correlations unless accuracies of EBV are close to one. Therefore, results should only be interpreted as general trends, keeping in mind that correlations between breeding values are always an underestimation of genetic correlations. Using the approximation of Calo et al. (1973), approximate genetic correlations were calculated and are also given in Table 5. Genetically, favorable animals are characterized by fewer disorders or the absence of disorders and high scores for type traits. Not surprisingly, genetic correlations were mostly negative among conformation traits describing the structure of feet and legs and individual claw or foot disorders. For example, the genetic correlation between foot angle and SU is -0.29 and suggests that animals with steeper angles are less susceptible to SU. For practical breeding decisions, results of correlations are favorable. Wells et al. (1993) found a similar relationship between foot angle and clinical lameness on the phenotypic scale. They reported an odds ratio of 2.4 for a decrease of $10^{\circ}$ in the angle of the rear lateral claw. Rear leg rear view is a trait with an intermediate optimum. Values $<100$ indicate steep legs that seemed to be favorable. We found that bulls that transmitted straighter legs viewed from the rear side had fewer daughters with claw and foot disorders. Phenotypic estimates from some studies indicate that cows slightly straighter than midrange for rear legs side view might be most desirable (McDaniel, 1995). Cows with a higher feet and leg score, steeper foot angle, and straighter legs showed a genetically significantly better locomotion in an analysis conducted by Van Dorp et al. (2004). Applying linear and threshold models Boettcher et al. (1998) found that low foot angle, hocking in, and wide rumps were mostly associated with clinical lameness. Genetic correlation between clinical lameness and rear legs side view was essentially zero, indicating that neither posty nor sickled hocks were strongly associated with clinical lameness. Boelling et al. (2001) estimated genetic correlations between hoof measurements and claw diseases in future AI bulls and body conformation traits in their daughters of the breeds Danish Red, Danish Friesian, and Jersey. The correlations of claw diseases of bulls with linear type scores of daughters for foot angle, rear leg side view, rear leg rear view, and quality of hocks were either negligible or inconclusive.

In our study, among the other type traits such as stature, dairy character, or body depth, correlations were not significantly different from zero, but strong cows seemed to be at higher risk concerning SD, WD, and IH. Boettcher et al. (1998) reported that genetic correlations between clinical lameness and body depth, strength, and rump width were moderate and positive, 
Table 6. Correlation between index and aggregate genotype $\left(\mathrm{r}_{\mathrm{TI}}\right)$ and selection response from one round of selection for different breeding scenarios (section intensity $=1$ ).

\begin{tabular}{llll}
\hline & & & $\begin{array}{l}\text { Selection } \\
\text { response } \\
\text { (reduction of } \\
\text { incidences per } \\
\text { generation) }\end{array}$ \\
\hline Index source & $\begin{array}{l}\text { Breeding } \\
\text { goal }\end{array}$ & $\mathrm{r}_{\mathrm{TI}}$ & \\
\hline Foot angle & Sole ulcer & 0.239 & 0.041 \\
Sole ulcer & Sole ulcer & 0.723 & 0.122 \\
Foot angle + sole ulcer & Sole ulcer & 0.731 & 0.124 \\
\hline
\end{tabular}

but correlations were close to zero for stature. We found a correlation near zero between all types of claw and foot diseases and dairy character. Other studies (Hansen et al., 2001) reported antagonistic relationships between dairy character and other diseases, except mastitis. They suggested that dairy character should be given a negative rather than a positive weight in the breeding goal.

Utilizing the phenotypic and genetic parameters obtained in the first part of the current study for SU and genetic parameters estimated by Bünger (1999) for foot angle, 2 different breeding scenarios were developed. This was done to combine type traits (foot angle) and claw disorders (SU) in selection index procedures. The alternatives included selection based on foot angle alone, which is common practice at the moment; SU; and a combination of both. The general breeding goal is to improve claw health within the Holstein population. Therefore, the only trait defined in the aggregate genotype was SU. Applying the selection index procedure using the SIP computer program (Wagenaar et al., 1995) and assuming 50 daughter records per sire, the correlation between the index and the aggregate genotype was calculated and compared for the 3 different scenarios. Assuming a standardized selection intensity equal to 1.0, selection response for the trait in the aggregate genotype was calculated. Phenotypic and genetic correlations, respectively, between SU and foot angle for selection index calculations were -0.02 and -0.29 . As shown in Table 6, inclusion of claw disorders in index sources will increase reliabilities of EBV and expected selection response for foot health substantially. Because of the moderate correlations between SU and foot angle, inclusion of foot angle in selection decisions will lead to marginal additional benefits in estimated reliabilities and genetic gains for SU. Genetic progress toward foot health can be tripled by recording and using detailed foot disease records for selection.

\section{CONCLUSIONS}

The individual herd management prevalently describing husbandry and feeding strategies was the most important factor affecting incidences of all claw and foot disorders significantly. The number of parities was only significant for SU and WD, but not for IH and DD. Heritability estimates for claw and foot disorders were low to moderate using logit link-functions in evaluation models. Nevertheless, heritability estimates are large enough to make selection for reduced health problems feasible. Furthermore, a strong relationship was observed between milk yield in the first stage of lactation and disorders. Continued selection for high production may increase the proportion of cows in extreme negative energy balance during early lactation causing health problems. Most claw and foot diseases occurred together genetically; this was also the case for claw and foot diseases and increased SCS. Correlations between breeding values of claw and foot disorders and functional type traits describing the conformation of feet and legs were generally favorable. High scores for stature, strength, and BW seemed to be negatively associated with incidences of SU. The results of our study underline the importance of accurate and complete data recording of individual disorders. At the moment, selection for improved feet and leg health is practiced indirectly based on conformation traits, but direct selection on individual disorders will be a new opportunity to improve selection response toward functional health in dairy cows. The establishment of an identical guideline for classification of individual claw and foot disorders within all regions of Germany, as developed by the German Agricultural Society, will allow such detailed recording systems.

\section{ACKNOWLEDGMENTS}

The authors thank Michael Kloo (Saxony, Germany) for providing the claw database and the VIT (Verden) for preparing the pedigrees and production data.

\section{REFERENCES}

ADR. 1980-2000. Annual Statistics. German Cattle Breeders Federation, Bonn, Germany.

Ali, A. K. A., and G. E. Shook. 1980. An optimum transformation for somatic cell concentration in milk. J. Dairy Sci. 63:487-490.

Animal and Plant Health Inspection Service. 1996. Part 1. Reference of 1996 Dairy Management Practices. National Animal Health Monitoring System, United States Dep. Agric., Fort Collins, CO.

Baumgartner, C. F., and O. Distl. 1988. Untersuchungen über Klauenmaße als Hilfsmerkmale für die Bullenmütterselektion auf Klauengesundheit an Töchtergruppen von Deutschen Fleckviehbullen. Dissertation, München, Germany.

Bergfeld, U. 2004. Zukünftige Anforderungen an die RinderzuchtKonsequenzen für die Leistungsprüfung und Zuchtwertschätzung. DGFZ-Schriftenreihe 13:31-51.

Blanchard, P. J., R. W. Everett, and S. R. Searle. 1983. Estimation of genetic trends and correlations for Jersey cattle. J. Dairy Sci. 66:1947-1954.

Boelling, D., P. Madsen, and J. Jensen. 2001. Genetic parameters of foot and leg traits in future AI bulls: Correlation to body conformation traits in daughters. Acta Agric. Scand. 51:122-128. 
Boettcher, P. J., J. C. M. Dekkers, L. D. Warnick, and S. J. Wells. 1998. Genetic analysis of clinical lameness in dairy cattle. J. Dairy Sci. 81:1148-1156.

Bünger, A. 1999. Die Länge des produktiven Lebens und ihre Beziehung zu linearen Exterieurmerkmalen bei Holstein-Friesian Kühen. Dissertation, Göttingen, Germany.

Calo, L. L., R. E. McDowell, L. D. Van Vleck, and P. D. Miller. 1973 Genetic aspects of beef production among Holstein-Friesians pedigree selected for milk production. J. Anim. Sci. 37:676-682.

Clarkson, M. J., D. Y. Downham, W. B. Faull, J. W. Hughes, F. J. Manson, J. B. Merrit, R. D. Murray, W. B. Russel, J. E. Suerst, and W. R. Ward. 1996. Incidence and prevalence of lameness in dairy cattle. Vet. Rec. 138:563-567.

Collard. B. L., P. J. Boettcher, J. C. M. Dekkers, D. Petitclerc, and L. R. Schaeffer. 1999. Relationships between energy balance and health traits of dairy cattle in early lactation. J. Dairy Sci. 83:2683-2690.

de Haas, Y., de, H. W. Barkema, and R. F. Veerkamp. 2001. Genetic parameters of pathogen-specific incidence of clinical mastitis in dairy cows. Br. Soc. Anim. Sci. 77:233-242.

Distl, O., D. S. Koorn, B. T. McDaniel, D. Peterse, R. D. Politiek, and A. Reurink. 1990. Claw traits in cattle breeding programs: Report of the EAAP working group 'claw quality in cattle.' Livest. Prod. Sci. 25:1-15.

Enevoldsen. C., and Y. T. Gröhn. 1990. Sole ulcers in dairy cattle: Associations with season, cow characteristics, disease, and production. J. Dairy Sci. 74:1284-1298.

Enting, H., D. Kooij, A. A. Dijkhuizen, R. B. M. Huirne, and E. N. Nordhuizen-Stassen. 1997. Economic losses due to clinical lameness in dairy cattle. Livest. Prod. Sci. 49:259-267.

Fatehi, J., A. Stella, J. J. Shannon, and P. J. Boettcher. 2001. Genetic parameters for feet and leg traits evaluated in different environments. J. Dairy Sci. 86:661-666.

Fleischer, P., M. Metzner, M. Beierbach, M. Hoedemaker, and W. Klee. 2001. The relationship between milk yield and the incidence of some diseases in dairy cows. J. Dairy Sci. 84:2025-2035.

Gilmour, A. R., B. J. Gogel, B. R. Cullis, and R. Thompson. 1998. ASREML User Guide. Release 1.0. NSW Agriculture, Orange, Australia.

Greenough, P. R. 1991. A review of factors predisposing to lameness in cattle. Pages 371-393 in Breeding for Disease Resistance in Farm Animals. C.A.B International, Wallingford, UK.

Hansen, M., M. S. Lund, M. K. Sorensen, and L. G. Christensen. 2001. Genetic parameters of dairy character, protein yield, clinical mastitis, and other diseases in the Danish Holstein cattle. J. Dairy Sci. 85:445-452.

Heringstad. B., G. Klemtsdal, and J. Ruane. 2000. Selection for mastitis resistance in dairy cattle-A review with focus on the situation in Nordic countries. Livest. Prod. Sci. 64:95-106.

Huang, Y. C., and R. D. Shanks. 1995. Within herd estimates of heritabilities for six hoof characteristics and impact of dispersion of discrete severity scores on estimates. Livest. Prod. Sci. 44:107-114

Huang, Y. C., and R. D. Shanks. 2002. Genetic aspect of foot abscess, heel warts and interdigital hyperplasia in dairy cattle. J. Chin. Soc. Anim. 31:141-155.
Kossaibati, M. A., and R. J. Esslemont. 2000. The incidence of lameness in 50 dairy herds in England. Pages 160-163 in Proc. 11th Int. Symp. Disorders of the Ruminant Digit, Parma, Italy.

Littell, R., G. Milliken, W. Stroup, and R. Wolfinger. 1999. SAS System for Mixed Models. SAS Inst., Inc., Raleigh, NC.

Lyons, D. T., A. E. Freeman, and A. L. Luck. 1990. Genetics of health traits in cattle. J. Dairy Sci. 74:1092-1100.

Mäntysaari, E. A., Y. T. Gröhn, and R. L. Quaas. 1991. Clinical ketosis: Phenotypic and genetic correlations between occurrences and with milk yield. J. Dairy Sci. 74:3985-3993.

McDaniel, B. T. 1995. Genetics and importance of feet and legs in dairy cattle. Presented at 46th Mtg. EAAP, Prague, Czech Republic.

Paget, M. F., G. J. T. Swanson, and R. A. Mrode. 2004. Genetic parameters for locomotion and composite type traits for the Jersey and Guernsey dairy breeds in the United Kingdom (UK). Page 164 in Proc. Br. Soc. Anim. Sci. 164.

Rodriguez-Zas, S. L., D. Gianola, and G. E. Shook. 1997. Factors affecting susceptibility to intramammary infection and mastitis: An approximate Bayesian analysis. J. Dairy Sci. 80:75-85.

Sander-Nielsen, U., G. A. Pedersen, J. Pedersen, and J. Jensen. 1996. Genetic parameters for mastitis, other diseases and somatic cell count in different parities in Danish dairy breeds. 47th Mtg. EAAP, Lillehammer, Norway.

Smits, M. C. J., K. Frankena, J. H. M. Metz, and J. P. T. M. Nordhuizen. 1992. Prevalence of digital disorders in zero-grazing dairy cows. Livest. Prod. Sci. 32:231-244.

Somers, J. G. C. J., K. Frankena, E. N. Noordhuizen-Stasssen, and J .H. M. Metz. 2003. Prevalence of claw disorders in Dutch dairy cows exposed to several floor systems. J. Dairy Sci. 86:2082-2093.

Southey, B. R., S. L. Rodriguez-Zas, and K. A. Leymaster. 2003. Discrete time survival analysis of lamb mortality in a terminal sire composite population. J. Anim. Sci. 81:1399-1405.

Uribe, H. A., B. W. Kennedy, S. W. Martin, and D. G. Kelton. 1995. Genetic parameters for common health disorders of Holstein cows. J. Dairy Sci. 78:421-430.

Van Dorp, T. E., P. Boettcher, and L. R. Schaeffer. 2004. Genetics of locomotion. Livest. Prod. Sci. 90:247-253.

Van Dorp, T. E., J. C. M. Dekkers, S. W. Martin, and J. P. T. M. Noordhuizen. 1998. Genetic parameters of health disorders, and relationships with 305-day milk yield and conformation traits of registered cows. J. Dairy Sci. 81:2264-2270.

Wagenaar, D., J. van Arendonk, and J. Kramer. 1995. Selection Index Program (SIP), User manual, Version 1.0. Department of Animal Breeding, Wageningen, The Netherlands.

Warnick, L. D., D. Janssen, C. L. Guard, and Y. T. Gröhn. 2001. The effect of lameness on milk production in dairy cows. J. Dairy Sci. 84:1988-1997.

Wells, S. J., A. M. Trent, W. E. Marsh, and R. A. Robinson. 1993. Prevalence and severity of lameness in lactating dairy cows in a sample of Minnesota and Wisconsin herds. JAVMA 202:78-82.

Wolfinger, R., and M. O'Connell. 1993. Generalized linear mixed models: A pseudo-likelihood approach. J. Stat. Comp. Simul. 48:233-243. 